\title{
$\stackrel{\circ}{\mathcal{C}}$ \\ Jurnal Civics: Media Kajian Kewarganegaraan \\ https://journal.uny.ac.id/index.php/civics/index \\ 1829-5789 (print) \\ 2541-1918 (online)
}

\section{Analisis nilai-nilai dalam Undang-Undang Simbur pada masyarakat Ogan Ilir}

\author{
Asmaul Husna a, ${ }^{*}$, Alfiandra ${ }^{\text {b, }, \text {, Sri Artati Waluyati }}{ }^{\text {c, } 3}$ \\ a, SMK Negeri 1 Penukal, Sumatera Selatan, Indonesia \\ b,c Program Studi Pendidikan Pancasila dan Kewarganegaraan, Fakultas Keguruan dan Ilmu \\ Pendidikan, Universitas Sriwijaya, Palembang, Indonesia \\ 1 asmaulh42@gmail.com*; alfiandra62@yahoo.com; sriartatiwaluyati@yahoo.co.id \\ *korespondensi penulis
}

\begin{tabular}{ll}
\hline \multicolumn{2}{l}{ Informasi artikel } \\
\hline Sejarah artikel: & \\
Diterima & $: 04-06-2018$ \\
Revisi & $: 02-02-2019$ \\
Dipublikasikan & $: 31-03-2019$ \\
\hline
\end{tabular}

\section{Kata kunci:}

Undang-undang Simbur Cahaya

Nilai religius

Moral

Etika

Sosial-politik

\begin{abstract}
ABSTRAK
Penelitian ini bertujuan untuk mengetahui nilai-nilai yang terkandung dalam Undang-undang Simbur Cahaya yang masih diamalkan masyarakat Sakatiga Kecamatan Indralaya. Sampel diperoleh dengan menggunakan teknik purposive sampling dan snowball sampling dengan jumlah informan sebanyak enam orang yang terdiri dari masyarakat Desa Sakatiga dan dua informan pendukung dari Kesultanan Palembang Darussalam dan Budayawan Palembang. Teknik pengumpulan data yang digunakan adalah dokumentasi, wawancara, dan observasi. Uji keabsahan yang dilakukan dalam penelitian ini adalah uji credibility, uji transferability, uji dependability, dan uji confirmability. Teknik analisis data yang digunakan adalah reduksi data, penyajian data, dan verifikasi data. Nilai-nilai yang terkandung dalam Undang-undang Simbur Cahaya yang masih diamalkan oleh masyarakat yaitu nilai religius atau agama, nilai moral/etika, nilai sosial, dan nilai politik.
\end{abstract}

\section{ABSTRACT}

The research purpose to know the values of containing in the Simbur Cahaya constitution still be practiced by Sakatiga. The sample is got by using the purposive sampling technique and snowball sampling with the amount of information was six-person that be consists of the people from Sakatiga and two the supporting information from Palembang Darussalam Sultanate and Cultural Palembang. The valid test is done in this researched was the credibility test, transferability, dependability, and confirmability test. The technique collecting of data be used was documentation, interview, and observation. Then the technique analysis of data that be used reduced of data, presentation of data, verification of data. Based on the result of analyzing data and discussion could know that values of containing in the Simbur Cahaya Constitution still be practiced by Sakatiga people in the Indralaya subdistrict that religion value, moral valuelethic, social value, and politic value.

\section{Copyright (C) 2019 Asmaul Husna, dkk}

\section{Pendahuluan}

Wilayah nusantara menghampar luas dengan ratusan suku bangsa dan memiliki kearifan lokal nilai-nilai kerukunan dalam keberagaman. Di nusantara inilah peradaban lokal tumbuh dan berkembang pada masanya. Palembang merupakan salah satunya, dan merupakan kota tertua yang ada di Indonesia dulunya merupakan wilayah Kerajaan Sriwijaya yang mempunyai kekuatan politik terbesar di kawasan Asia Tenggara (Utomo, Hanafiah, \& Ambari, 2005). Setelah Kerajaan Sriwijaya runtuh, Palembang berubah menjadi sebuah Kerajaan Islam yang kemudian bertransformasi menjadi Kesultanan Palembang Darussalam. Berbeda dengan Kerajaan Islam, Kesultanan Palembang Darussalam lebih bermotif Islam karena mengamalkan Islam serta menjadikan al-Quran dan hadis sebagai konstitusi 
pemerintahan (Syawaludin, 2014). Berbagai keberhasilan dan kegemilangan Kesultanan Palembang terdahulu membuat Palembang menjadi Kota yang patut diperhitungkan di Nusantara dan mendapat banyak predikat atas keberhasilan pembangunan mulai dari politik, ekonomi, dan sosialnya (Ravico, 2015).

Palembang juga mendapat sebutan net indische Venetie (Venesia di Hindia Belanda), bahkan nama Darussalam diterjemahkan de stad des vredes yang berarti tempat yang tenteram karena sangat kental dengan nilainilai keislaman membuat masyarakatnya memiliki nilai religius yang tinggi dalam hal kearifan lokal (Amri \& Maharani, 2018). Dengan demikian pada masa Kerajaan Palembang Islam, tepatnya di era pemerintahan Ratu Jamaluddin Mangkurat IV atau yang lebih dikenal dengan Pangeran Sedo Ing Kenayan yang memerintah 1639-1650 M, dibentuk sebuah hukum adat bercorak Islam dan berfungsi mengatur segala aktivitas kemasyarakatan di wilayah Uluan dan sekitarnya. Hukum adat inilah yang kemudian dikenal dengan sebutan Undang-undang Simbur Cahaya (Gadjahnata \& Swasono, 1986). Adapun yang pertama kali menyusun undang-undang ini adalah permaisuri raja yang bernama Ratu Sinuhun. Oleh karena itulah, undang-undang ini juga dikenal dengan sebutan "Undang-undang Ratu Sinuhun" (Farida \& Hasan, 2011).

Secara etimologis, Simbur Cahaya sendiri berarti percik sinar. Kata ini dihubungkan dengan cerita mitos tentang selimbur (pancaran) cahaya yang terjadi di bukit Siguntang menyambut kedatangan anak cucu Iskandar Zulkarnain. Makna fungsionalnya bahwa Simbur Cahaya sebagai cahaya atau sinar. Sinar tersebut berfungsi sebagai obor atau suluh untuk menerangi jalan hidup masyarakat Sumatera Selatan. Karena tafsir dari norma yang terkandung dalam Simbur Cahaya itu sendiri sebagai suatu sistem peradatan yang berlaku di uluan Palembang, Sumatera Selatan sejak ratusan tahun yang lalu. Konsep Iliran dan Uluan secara geografis dapat dibagi menjadi dua, Iliran untuk kawasan pusat kota Palembang lama yang identik dengan majunya peradaban, sedangkan Uluan adalah seluruh kawasan yang berada di luar kawasan Palembang Lama, sebagai kawasan penunjang peradaban (Santun, Murni, \& Supriyanto, 2010). Perspektif politik, ekonomis dan sosial budaya, konsep Iliran dan Uluan sendiri dalam pada masyarakat Sumatera Selatan telah ada sejak masa lampau dalam kurun sejarahnya. Dari catatan sejarah yang ada kita ketahui bahwa raja-raja/sultan-sultan Palembang berasal dan memiliki hubungan darah dengan raja-raja Jawa. Oleh karena itu, sistem pemerintahan yang mereka anut adalah sistem pemerintahan yang terdapat dari mana mereka berasal (Santun et al., 2010). Model pemerintahan "Catur Menggala" yang ada di Jawa, diadopsi di Palembang dan dikenal dengan istilah "Empat Manca Negara", yang terdiri dari Raja/Sultan, Pepatih, Penghulu dan Kepala Pengalasan (Jaksa). Namun tampaknya sistem pemerintahan seperti itu hanyalah berlaku di ibukota, sedangkan di daerah uluan (pedalaman) yang pada saat itu menganut sistem pemerintahan marga, tetap berlangsung sebagaimana adanya (Ismail, 2004).

Oleh karena itu campur tangan raja/sultan terhadap sistem pemerintahan marga tidak terlalu mendalam. Setiap marga menjadi "raja kecil" di daerahnya dan tetap mengatur rumah tangganya sendiri. Mereka dibebaskan dari kewajiban membayar pajak, namun mereka diberikan semacam tugas-tugas khusus untuk membantu pemerintah pusat. Daerah-daerah tersebut dikenal dengan istilah daerah sikap, yang merupakan adopsi model daerah perdikan yang ada di Jawa. Termasuk dalam kategori daerah sikap ini di antaranya yaitu daerah Belida (sekitar Muara Enim sekarang) dan Pegagan (sekarang daerah Ogan Ilir, termasuk di dalamnya Sakatiga yang menjadi lokasi dalam penelitian ini) (Ismail, 2004).

Pada masa pemerintahan Pangeran Sedo Ing Kenayan (suami dari Ratu Sinuhun) yang memerintah 1639-1650, dilembagakan suatu aturan yang dapat mengikat dan mendorong orientasi para kepala marga dalam suatu kesatuan dengan membuat aturan-aturan adat pertama di daerah Uluan yang kemudian dikenal dengan sebutan "Undang-undang Simbur Cahaya" (Gadjahnata \& Swasono, 1986). 
Berdasarkan uraian latar belakang di atas maka menjadi pertanyaan mengenai nilai-nilai yang terkandung dalam Undang-undang Simbur Cahaya masih diamalkan oleh masyarakat dengan tujuan untuk mengetahui nilai-nilai yang terkandung dalam Undangundang Simbur Cahaya yang masih diamalkan oleh masyarakat Ogan Ilir.

\section{Metode}

Penelitian ini menggunakan empat indikator untuk mengetahui nilai-nilai Undang-undang Simbur Cahaya yang masih diamalkan di masyarakat Desa Sakatiga Kecamatan Indralaya. Empat indikator itu meliputi nilai religius/agama, nilai moral/etika, nilai politik dan nilai sosial yang terkandung dalam pasal-pasal di aturan bujang gadis dan kawin, aturan marga, aturan dusun dan berladang, dan aturan perhukuman Undang-undang Simbur Cahaya. Penelitian kualitatif tidak menggunakan istilah populasi, tetapi oleh Spradley dinamakan "social situation" atau situasi sosial yang terdiri atas tiga elemen yait tempat, pelaku, dan aktivitas yang berinteraksi secara sinergis (Sugiyono, 2014). Oleh karena itu, social situation yang dimaksud dalam penelitian ini adalah "nilainilai yang terkandung dalam Undang-undang Simbur Cahaya yang masih diamalkan oleh masyarakat Ogan Ilir" dengan rincian Desa Sakatiga Kecamatan Indralaya sebagai tempat yang diteliti (place), masyarakat yang berdomisili di desa tersebut sebagai pelaku (actors), dan sikap/kebiasaan mereka yang masih mengamalkan nilai-nilai Undangundang Simbur Cahaya sebagai aktivitas yang diteliti (activity).

Penentuan narasumber/informan dalam penelitian ini awalnya ditentukan lewat teknik purposive sampling, yaitu dipilih dengan penilaian dan alasan serta tujuan yang telah ditentukan, misalnya orang-orang yang dianggap memahami situasi sosial atau masalah yang akan diteliti (Sugiyono, 2014). Tetapi karena peneliti membutuhkan data yang lebih banyak lagi, maka untuk melengkapinya, peneliti mencari informan yang lain yang mampu memberikan data lebh banyak sehigga di dapatkan informasi lebih lengkap dari sebelumnya. Oleh karena itulah, digunakanlah teknik snowball sampling yaitu penetuan jumlah sampel yang awalnya jumlahnya kecil, kemudian membesar terus mebesar sesuai. Dengan jumlah informan sebanyak enam orang yang terdiri dari masyarakat asli Desa Sakatiga dan dua informan pendukung dari Kesultanan Palembang Darussalam dan Budayawan Palembang.

Untuk teknik pengumpulan data, peneliti menggunakan teknik dokumentasi, wawancara dan observasi. Kemudian uji keabsahan data yang digunakan dalam penelitian ini adalah uji credibility, uji transferability, uji dependability, dan uji confirmability. Selanjutnya terakhir teknik analisis data yang digunakan adalah teknik analisis data kualitatif yang meliputi reduksi data, penyajian data dan penarikan kesimpulan.

Penelitian ini dilakukan di Desa Sakatiga Kecamatan Indralaya Kabupaten Ogan Ilir. Tempat ini dipilih karena dulunya merupakan kawasan yang memainkan peranan penting dalam sejarah Kerajaan Palembang Islam dan juga di zaman Kesultanan Palembang Darussalam, yang zaman dahulu dikenal dengan sebutan daerah sikap. Dilakukan mulai dari tanggal 14 September 2015 sampai dengan 14 Oktober 2015. Dalam penelitian ini peneliti mengumpulkan data dan informasi melalui teknik dokumentasi, teknik wawancara dan teknik observasi. Melalui teknik dokumentasi peneliti mengumpulkan data dan informasi berupa gambaran umum tentang letak wilayah dan keadaan Desa Sakatiga, sejarah berdirinya desa, struktur kepengurusan desa dan jumlah penduduk, mata pencaharian, dan sarana dan prasarana Desa Sakatiga. Selanjutnya untuk teknik wawancara peneliti melakukan wawancara dengan enam orang informan utama dan dua orang informan pendukung. Wawancara dilakukan sampai semua data yang dibutuhkan diperoleh peneliti. Setelah itu melalui teknik observasi peneliti mengobservasi nilai-nilai yang terkandung dalam Undang-undang Simbur Cahaya yang masih diamalkan oleh masyarakat Desa Sakatiga sesuai dengan hasil wawancara sebelumnya. 


\section{Hasil dan Pembahasan}

Sebagai salah satu karya kesusastraan lama, hasil karya kesusastraan masa lampau banyak mengandung nilai-nilai luhur yang menjadi sumber pegangan dalam bersikap dan bertingkah laku bagi masyarakat ke arah kebenaran. Hal ini dapat kita lihat dari setiap makna dalam pasal-pasal yang ada dalam undang-undang tersebut. Nilai-nilai sendiri secara sederhana dapat kita artikan sebagai sikap dan prinsip yang dimiliki oleh seseorang, dimana sikap dan prinsip tersebut berupa kebaikan, kejujuran, kebenaran dan pemberian arah serta makna pada kehidupan seseorang, yang bersumber dan berakar dari kehidupan masyarakat Palembang, dan kemudian menjadi dasar atau pijakan bagi terbentuknya Undang-Undang Simbur Cahaya. Salah satu tempat yang dianggap masih memegang erat dan mengamalkan nilai-nilai Undang-undang Simbur Cahaya tersebut adalah kawasan Desa Sakatiga Kecamatan Indralaya Kabupaten Ogan Ilir. Pemilihan tempat ini bukanlah karena merupakan kawasan yang memainkan peranan penting dalam sejarah Kerajaan Palembang Islam dan juga di zaman Kesultanan Palembang Darussalam, yang zaman dahulu dikenal dengan sebutan daerah sikap. Sakatiga juga merupakan tempat pelarian dari Pangeran Sedo Ing Rejek (Raja Palembang terakhir) yang merupakan keponakan langsung dari Ratu Sinuhun, penyusun Undang-undang Simbur Cahaya. Kemudian, tempat ini juga dikenal dengan sebutan "Kota Santri", lantaran begitu kentalnya masyarakat di daerah ini memegang nilai-nilai keislaman, yang mana kita tahu sumber utama nilai-nilai yang terkandung dalam Undang-undang Simbur Cahaya adalah ajaran Islam. Hal tersebut juga di dukung oleh penelitian sebelumnya yang dilakukan oleh Wirajaya (Wirajaya, 2018, hal. 35) bahwa "Undang-undang Simbur Cahaya merupakan suatu hukum yang mengombinasikan antara hukum adat dan hukum Islam yang mengatur berbagai aspek kehidupan masyarakat demi keserasian dan kelestarian hidup manusia". Adapun yang tak kalah pentingnya, kitab hukum adat ini merupakan hukum adat tertulis pertama yang berlandaskan syariat Islam yang diterapkan di bumi nusantara (Adil Muhammad, 2014).

Beberapa hal yang ditemukan dalam penelitian ini yakni, pertama, Pada Bab I (Aturan Bujang Gadis dan Kawin) Pasal 1, "Djikalau bujang gadis hendak kawin, hendaklah orang tua budjang dan orang tua gadis itu memberitahukannya pada pasirah atau kepala dusun, itulah "terang" namanja dan budjang itu harus membajar "adat terangnja" itu (upah tua atau upah-batin) sebanjak 3 ringgit". Nilai yang terkandung dalam pasal ini adalah nilai moral/etika, nilai politik, dan nilai sosial. Pelaksanaan pasal ini dapat dikatakan sudah menjadi kebiasaan masyarakat yang dalam praktiknya mesti dilaksanakan. Adapun maknanya adalah sebagai bentuk penghormatan masyarakat terhadap penguasa/pemerintah di desa tersebut. "Adat beterangan", artinya berkumpulnya kedua keluarga baik dari pihak laki-laki maupun perempuan untuk bermusyawarah mempersiapkan pernikahan. Dalam proses "adat beterangan" ini juga pihak laki-laki memberikan sejumlah uang hormat kepada orang tua si perempuan yang jumlahnya tergantung kesepakatan antara kedua belah pihak, dikenal dengan istilah "upah tua".

Kedua, Pada Bab I (Aturan Bujang Gadis dan Kawin) Pasal 4, "Belanja dapur atau "belandja kawin” budjang jang membayar. Djika budjang jang kawin berada, boleh ia mengadakan kenduri besar dan djika ia miskin mestilah ia mengadakan kenduri kedjil dan untuk belandja dapur tiada boleh ia berutang pada mertuanja atau ahli isterinja". Nilai yang terkandung dalam pasal ini adalah nilai moral/ etika dan nilai sosial. Pelaksanaan pasal ini sudah menjadi kebiasaan masyarakat setempat sebagai perbuatan yang harus dilaksanakan oleh laki-laki yang ingin menikah, kegiatan ini juga sebagai simbol sikap hormat laki-laki kepada orang tua perempuan yang akan dinikahinya. Ketika seorang laki-laki akan menikahi seorang perempuan maka semua biaya pernikahan yang bersifat administrasi dan "uang asap" ditanggung oleh pihak laki-laki dengan tidak boleh berhutang kepada mertuanya. 
Ketiga, Pada Bab I (Aturan Bujang Gadis dan Kawin) Pasal 5, “.........Djika gadis jang kawin mempunjai kakak perempuan jang belum bersuami, hendaklah budjang membadjar padannja "adat pelangkah" 2 ringgit dan djika rand jang kawin, tidak membajar jang tersebut diatas, melainkan boleh membajar adat pengamitan 1 ringgit". Nilai yang terkandung dalam pasal ini adalah nilai moral/etika, dan nilai sosial. Adat "pelangkah" ini menjadi adat yang harus dilaksanakan oleh laki-laki jika ingin menikahi perempuan yang mempunyai kakak yang belum menikah. Kegiatan ini dilakukan sebagai bentuk sikap penghormatan kepada kakak dari perempuan yang kelak dinikahinya.

Keempat, pada Bab I (Aturan Bujang Gadis dan Kawin) Pasal 12, "Djika ada budjang gadis akan dipertunangkan hendaklah bapak budjang mengantarkan djuadah (dodol) pada kepala dusun dan penggawanja, sesudah itu barulah "terang" namanja". Nilai yang terkandung dalam pasal ini adalah nilai moral/etika dan nilai politik. Aturan ini dilaksanakan sebagai bentuk sikap hormat masyarakat kepada penguasa/pemerintah desa setempat. Kebiasaan ini sudah berlangsung sejak sekian lama dan dalam perkembangannya selalu dilaksanakan oleh masyarakat. Pelaksanaan adat ini dilakukan ketika ada laki-laki dan perempuan yang akan menikah maka orang tua laki-laki mengantarkan juada (dodol) kepada kepala dusun, khatib, lembaga adat dan lain sebagainya. Adat ini juga disebut sebagai adat "minta wali".

Kelima, pada Bab I (Aturan Bujang Gadis dan Kawin) Pasal 13, "Djika budjang-gadis telah bertunangan dengan terang dan gadis itu dibawa lari oleh budjang jang lain atau ahli gadis mungkir tiada suka lagi pada budjang jang meminang dengan tidak ada sebabnja jang patut, maka bapa gadis dikenakan denda 8 ringgit penjingsingan. Pada budjang, dan kerugiannja ditimbang menurut putusan rapat marga jang berkuasa untuk mendendanja, setinggi-tingginja 12 ringgit". Nilai yang terkandung dalam pasal ini adalah nilai moral/etika. Aturan ini sudah ada sejak lama dan sudah menjadi kebiasaan masyarakat setempat sebagai aturan yang tidak tertulis tetapi tetap ditaati oleh masyarakat. Jika laki-laki dan perempuan telah bertunangan, kemudian perempuan itu membatalkan pertunangannya tanpa sebab yang jelas, maka perempuan itu dikenakan denda untuk mengembalikan semua yang telah diberikan oleh laki-laki ketika adat "beterangan" sebanyak dua kali lipat.

Keenam, pada Bab I (Aturan Bujang Gadis dan Kawin) Pasal 14, "Djika seorang budjang membatalkan pertunangannja dengan tidak ada sebabnja, maka budjang itu tiada boleh menuntut kerugiannja". Nilai yang terkandung dalam pasal ini adalah nilai moral/etika. Aturan ini juga sebagai aturan yang masih dilaksanakan masyarakat walaupun tidak tertulis tetapi sudah menjadi kebiasaan. Jika laki-laki dan perempuan telah bertunangan kemudian laki-laki tersebut membatalkan pertunangannya dengan tidak ada sebab yang pasti, maka laki-laki tersebut tidak boleh menuntut kerugian bahkan dikenakan denda untuk membayar semua kerugian materiel yang telah dikeluarkan oleh pihak perempuan.

Ketujuh, pada Bab II (Aturan Marga) Pasal 3, "Di dalam dusun pasirah ditetapkan seorang lebai, jaitu seorang penghulu jang menguasai hukum (huk. Sjareat) dan seorang khatib jang menolong lebai dalam pekerdjaannja sehari-hari". Nilai yang terkandung dalam pasal ini adalah nilai politik. Pelaksanaan pasal ini masih ada sebagai suatu struktur dalam pemerintahan desa yang harus ada untuk membantu masyarakat misalnya dalam hal adat pernikahan dan kematian. Di masyarakat Sakatiga masih ada seorang penghulu yang diusulkan oleh masyarakat dan kemudian ditetapkan oleh pemerintah.

Kedelapan, pada Bab III (Aturan Dusun dan Berladang) pasal 5,"di tiap-tiap dusun diadakan kemit dusun jang terdiri dari 2 sampai 8 orang menurut patutan pasirah. Proatin dan kemit dusun itu bergiliran menurut permupakatan dusun: pekerdjaan kemit dusun siang dan malam ialah mendjaga api dan pendjuri serta memelihara halaman, pangkalan, gardu dan balairung”. Nilai yang terkandung dalam pasal ini adalah nilai 
politik. Aturan ini masih ada sebagai perintah kepala desa bahwa di setiap dusun harus ada orang-orang yang melakukan aktivitas ronda malam, tujuannya adalah untuk menjaga agar lingkungan setempat tetap aman dan tenteram. Pada masa sekarang ini tidak ada lagi istilah kemit tetapi sudah diganti dengan kamling (keamanan lingkungan) yang anggotanya terdiri dari masyarakat itu sendiri terdiri.

Kesembilan, pada Bab III (Aturan Dusun dan Berladang) pasal 7, "Barang siapa tidak datang pada waktu telah tiba gilirannja kemit dusunnja (putus gawe namannja) maka ia ia dikenakan hukuman di muka rapat marga". Nilai yang terkandung dalam pasal ini adalah nilai moral/etika. Aturan dalam pasal ini juga masih dilaksanakan oleh masyarakat walaupun tidak sama persis dengan aturan aslinya. Tujuannya adalah untuk menghargai dan menghormati orang-orang yang mendapat giliran berjaga di malam tersebut. Jika seseorang yang bertugas menjaga dusun pada malam hari (ronda malam) tidak bisa hadir maka ia harus mencari penggantinya dan membayar "upah rokok dan kopi" atau menyediakan rokok dan kopi kepada temanteman lain yang berjaga malam pada saat itu.

Kesepuluh, pada Bab III (Aturan Dusun dan Berladang) pasal 9, "Orang asing tidak dibenarkan tinggal di dusun dengan seizin kepala dusun. Barang siapa yang memberi tumpangan pada orang asing dirumahnnja maka ia bertanggung jawab atas segala perbuatan orang jang diberinnja tumpangan itu”. Nilai yang terkandung dalam pasal ini adalah nilai politik dan nilai moral/etika. Aturan ini sebagai sikap rasa hormat kepada pemerintah desa setempat dan sudah menjadi kebiasaan di masyarakat. Jika ada orang asing ingin tinggal di Sakatiga, maka orang tersebut harus lapor dan meminta izin terlebih dahulu kepada kepala desa. Jika ada masyarakat yang memberi tumpangan rumah kepada orang asing tersebut maka orang yang memberi tumpangan itu harus bertanggung jawab atas semua perbuatan yang dilakukan oleh orang yang diberi tumpangan.

Kesebelas, Pada Bab III (Aturan Dusun dan Berladang) pasal 12, "Ditiap-tiap dusun hendaklah orang banjak menegakkan balai, gardu, peseban dan mesdjid atau langgar".
Nilai yang terkandung dalam pasal ini adalah nilai sosial. Pelaksanaan aturan ini bertujuan untuk kepentingan masyarakat setempat dan untuk menumbuhkan sikap gotong-royong di antara masyarakat. Di Sakatiga sudah berdiri sebuah masjid, langgar, gardu dan balai desa. Di setiap dusun haruslah didirikan sebuah gardu yang dalam pembuatannya dilakukan oleh masyarakat setempat secara gotongroyong. Begitu pula dengan biayanya, juga merupakan sumbangan sukarela dari seluruh masyarakat.

Kedua belas, Pada Bab IV (Aturan Kaum) Pasal 10, "Dari selikur (21) sampai tiga puluh hari puasa kaum-kaum boleh minta fitrah kepada orang jang suka memberikannja. Lebai penghulu dan kaumkaum di dalam margannja membagi-bagikan fitrah itu sebagaimana mestinnja". Nilai yang terkandung dalam pasal ini adalah nilai religius dan nilai sosial. Masyarakat yang kurang mampu boleh meminta fitrah kepada yang suka memberinya. Masyarakat juga boleh mengumpulkan fitrah tersebut ke Badan Amil Zakat yang dibentuk oleh khatib bersama masyarakat atau langsung memberikannya kepada yang dipandang berhak menerima fitrah tersebut sesuai keinginan dari individu masing-masing.

Ketiga belas, pada Bab IV (Aturan Kaum) Pasal 11, "Djika seseorang suka memberikan zakatnja bolehlah kaum-kaum memungutnnja dan kaum-kaum harus membagi-bagikan kepada jang yang berhak memberinnja menurut agama (Islam)." Nilai yang terkandung dalam pasal ini adalah nilai religius dan nilai sosial. Pelaksanaan pembagian zakat ini boleh diberikan langsung oleh masyarakat kepada yang berhak menerimanya atau dikumpulkan di Badan Amil Zakat.

Keempat belas, pada Bab IV (Aturan Kaum) Pasal 12"Kaum-kaum hendaklah memelihara mesjid-mesjid, langgar-langgar, padasan-padasan dan keramat-keramat". Nilai yang terkandung dalam pasal ini adalah nilai religius. Dalam kehidupan sehari-hari, masjid-masjid di desa tersebut sangat makmur dalam artian masih ada aktivitas salat berjamaah, tahriman (membacakan ayat-ayat suci Al-Qur'an menjelang masuknya waktu 
salat). Namun demikian, walaupun sudah ada petugas masjid, tetapi masyarakat masih tetap bergotong-royong membersihkan masjid tersebut terutama ketika ada acara peringatan hari-hari besar Islam. Selain masjid atau langgar-langgar, masyarakat juga dikenal sangat menghormati makam-makam leluhurnya. Selain itu, terdapat makam keramat yang sampai sekarang terjaga dengan baik walaupun sudah berumur ratusan tahun yaitu makam Pangeran Sedo Ing Rejek yang merupakan Raja Palembang terakhir.

Kelima belas, Pada Bab IV (Aturan Kaum) Pasal 14, "Kaum-kaum hendaklah memandi dan menyembunjikan orang mati dengan tiada meminta pembajaran melainkan serela hati orang yang membajarnnja". Nilai yang terkandung dalam pasal ini adalah nilai religius dan nilai sosial. Jika ada orang meninggal dunia maka hendaklah yang memandikannya itu ahlinya. Orang-orang yang memandikan jenazah tersebut biasanya tidak meminta bayaran melainkan ikhlas membantu, kalaupun ada bayaran itu tidak ditetapkan tarifnya melainkan dengan keikhlasan hati orang yang memberi.

Keenam belas, Pada Bab IV (Aturan Kaum) Pasal 15, "Kaum-kaum hendaklah mengajar anak-anak di dalam dusunnja mengadji, menjurat dengan tiada memungut bajaran, melainkan serela hati orang jang memberinja". Nilai yang terkandung dalam pasal ini adalah nilai religius dan nilai sosial. Guru yang mengajar mengaji tidak meminta atau menetapkan bayaran khusus atas aktivitas mengajar yang dilakukannya, melainkan keikhlasan hati orang tua murid jika ingin memberi. Adapun mengenai waktu belajarnya biasanya sore hari, meski ada juga yang mengaji setelah salat magrib, subuh tau pagi hari.

Ketujuh belas, Pada Bab V (Aturan Perhukuman) Pasal 13, "Djika seseorang melakukan "tjempala tangan" artinya menempeleng, memukul, berkelahi di rumah orang, mentjabut kapak merusakkan tanaman atau rumah orang, maka jang bersalah harus memberikan kepada jang mendakwa beras satu gantang, kelapa atau bidji, ajam satu ekor, dan sirih satu kisal djika perkara itu ringan dan djika perkara itu ditimbang berat, didenda 12 ringgit serta diwadjibkan mengganti kerusakan atau kerugian". dan Pasal 16, "Djika ada orang berkelahi sampai berlukaan maka jang melukai harus membajar uang obat dari 2 sampai 8 ringgit, dan perkarannja diserahkan pada rapat jang berkuasa (bukan rapat marga)". Nilai yang terkandung dalam pasal ini adalah nilai moral dan nilai sosial. Jika ada orang melakukan "cempala tangan" artinya memukul, menempeleng, berkelahi dan lain sebagainya sehingga membuat orang lain terluka maka orang yang melakukan perbuatan tersebut dikenakan denda "tepung tawar" yaitu memberikan beras, ayam, gula dan lain sebagainya kepada korban. Hal ini dilakukan sebagai bentuk permintaan maaf sehingga korban tidak merasa tersinggung dan menyimpan dendam. Jika ada orang yang berkelahi sampai ada yang terluka maka orang-orang tersebut dibawa ke kepala dusun untuk didamaikan dan orang yang melukai harus memberikan sejumlah uang untuk berobat kepada yang dilukainya nilai yang terkandung dalam pasal ini adalah nilai moral dan nilai sosial, dan nilai politik.

Selain melakukan wawancara dengan informan utama yaitu masyarakat Sakatiga, peneliti juga mewawancarai dua orang informan pendukung yaitu Sultan Palembang Darussalam dan budayawan Palembang. Dari hasil wawancara tersebut didapatkan informasi bahwa kedua informan mempunyai pendapat yang sama jika nilai-nilai yang terkandung dalam Undang-Undang Simbur Cahaya masih ada di kehidupan masyarakat Sumatera Selatan, khususnya daerah-daerah Uluan Palembang seperti Ogan Ilir, Ogan Komering Ilir, Ogan Komering Ulu dan daerah lain di luar kota Palembang. Walaupun Undang-undang Simbur Cahaya tersebut secara formal sudah tidak berlaku lagi, tetapi masyarakat tetap mempertahankan nilai-nilai yang ada untuk menjaga etika dan perilaku masyarakat setempat. Sultan Palembang dan budayawan Palembang sangat berharap agar undang-undang ini dapat kembali diberlakukan karena undang-undang ini berangkat dari budaya asli masyarakat kita sendiri sehingga dengan mudah dapat dipatuhi oleh masyarakat setempat dan mampu

18| Jurnal Civics: Media Kajian Kewarganegaraan 
memberi efek jera kepada masyarakat yang melanggarnya. Selain itu, dengan kembali diberlakukannya Undang-undang Simbur Cahaya tersebut diharapkan dapat menyatukan masyarakat Sumatera Selatan yang latar belakangnya majemuk ini.

Selanjutnya, telah dilakukan beberapa upaya agar Undang-undang Simbur Cahaya tetap berlaku yaitu dengan diadakannya kegiatan-kegiatan seminar. Dan pada tahun 2012, Sultan Palembang Darussalam pernah diundang oleh balai legislasi DPR dan DPD untuk membuat suatu Rancangan Undangundang tentang hukum adat. Dan rencananya ada ada beberapa pasal dalam Undang-undang Simbur Cahaya yang akan dijadikan hukum positif di negara Indonesia. Sebenarnya hal tersebut di anggap wajar, karena memang sejak dulu hukum adat menjadi salah satu sumber terbentuknya hukum positif di Indonesia. Mulyadi (2013, hal. 245) mengungkapkan bahwa "kehadiran hukum pidana adat Indonesia berada pada tataran dogmatik hukum, teori hukum dan filsafat hukum". Oleh karena itu hukum pidana adat secara keseluruhan menjiwai lapisan ilmu hukum dalam praktik hukum sehingga prinsipnya hukum pidana adat tidak diragukan kapabilitas nya sebagai ciri praktik hukum di Indonesia.

Pada penelitian ini ada empat nilai-nilai yang masih diamalkan di masyarakat Sakatiga. Pertama, nilai religius atau nilai agama yaitu nilai yang bersumber pada kepercayaan terhadap Tuhan, dan menjalankan perintah Tuhan Yang Maha Esa. Kedua, nilai moral/etika yaitu nilai yang ada dalam diri seseorang, baik secara teori maupun praktik. Nilai-nilai moral yang ada pada diri seseorang dapat diinternalisasi sejak lahir, sehingga membentuk sikap dan perilaku seseorang yang bermoral (Wijaya, Widodo, \& Subiyantoro, 2017). Ketiga, adalah nilai sosial yaitu nilai yang berkiblat kepada korelasi antar manusia dan lebih menekankan pada segi-segi kemanusiaan yang luhur. Keempat, adalah nilai politik, yaitu nilai yang bersumber dengan kekuasan, pengambilan keputusan dari seseorang yang diberi wewenang (Alfan, 2013).
Nilai-nilai tersebut tetap dipertahankan sampai sekarang walaupun Undang-undang Simbur Cahaya itu tidak berlaku lagi karena menurut pendapat masyarakat sekitar, selama aturan itu baik dan tidak menyimpang dari hukum agama Islam maka nilai tersebut akan tetap dipertahankan dan dilestarikan dan sudah menjadi kebiasaan masyarakat sejak lama serta merupakan warisan budaya asli dari para leluhur mereka. Hal ini sesuai dengan pendapat Yusdani (2004) dalam penelitian sebelumnya mengatakan bahwa Dalam Undang-undang Simbur Cahaya terkandung nilai-nilai pendidikan moral dan etika bagi masyarakat Palembang pada umumnya, terutama mengenai pergaulan bujang gadis. Oleh karena itu, berbagai ajaran etika dan moral tersebut tetap harus dipertimbangkan dan digali demi pengembangan nilai-nilai budaya lokal daerah.

Alasan lain mengenai nilai-nilai yang terkandung dalam Undang-undang Simbur Cahaya ini masih tetap ada di tengah kehidupan masyarakat modern saat ini (khususnya masyarakat Desa Sakatiga), dikarenakan jika dilihat dari latar belakang penyusunannya, Undang-undang Simbur Cahaya selalu dihubungkan dengan nilai-nilai keislaman yang senantiasa berpedoman pada Al-Qur'an, hadis dan piagam-piagam. Hal ini sesuai dengan kondisi masyarakat Ogan Ilir yang dikenal dengan sebutan "Kota Santri", lantaran begitu kentalnya masyarakat di daerah ini memegang nilai-nilai keislaman tidak terkecuali juga dengan Desa Sakatiga yang seluruh penduduknya beragama Islam.

\section{Simpulan}

Masyarakat di Desa Sakatiga Kabupaten Ogan Ilir masih mengamalkan nilai-nilai yang terkandung dalam Undang-undang Simbur Cahaya. Walaupun secara resmi undangundang itu sudah tidak berlaku lagi, tetapi ia tetap menjadi adat-istiadat dan kebiasaan masyarakat setempat yang masih terus diamalkan hingga saat ini. Adapun di antara nilai-nilai yang masih diamalkan tersebut yaitu: Pertama, nilai religius atau nilai agama, yang terdapat dalam Bab IV (Aturan Kaum) yaitu pada pasal 10, 11, 12, 14 dan 15 . Selain 
nilai religius atau agama, aturan dalam bab ini juga mengandung nilai-nilai sosial. Kedua, nilai moral / etika, terdapat dalam Bab I (Aturan Bujang Gadis dan Kawin) yaitu pasal $1,4,5,12,13$ dan 14 , di dalam pasal di atas juga mengandung nilai politik dan nilai sosial. Ketiga, nilai politik, yang terdapat dalam Bab II (Aturan Marga) pada pasal 3, dan Bab III (Aturan Dusun dan Berladang) pada pasal 5, 7 dan 9. Selain nilai politik, dalam pasal ini juga terdapat nilai moral / etika. Keempat, nilai sosial, yang terdapat dalam Bab III (Aturan Dusun dan Berladang) pada pasal 12, dan Bab V (Aturan Perhukuman) pada pasal 13 dan 16. Berdasarkan simpulan di atas, maka peneliti menyarankan kepada beberapa pihak terkait sebagai berikut. Diharapkan pemerintah dapat lebih memperhatikan kearifan lokal yang ada di masyarakat khususnya masyarakat Sumatera Selatan dan tetap berupaya agar adat-istiadat yang baik itu tetap dijaga dan dilestarikan. Kemudian, masyarakat Sakatiga tetap menjaga dan melestarikan nilai-nilai yang terkandung dalam Undang-undang Simbur dan menjadikan adat istiadat itu sebagai kebiasaan yang harus dijalankan sebagai kekayaan budaya dan adat di masyarakat setempat. Dan Diharapkan peneliti dapat menjadikan hasil penelitian yang ini sebagai pengalaman dan pengetahuan yang baru sehingga nantinya juga dapat ikut mempertahankan dan melestarikan nilai-nilai tersebut.

\section{Ucapan Terima Kasih}

Penulis mengucapkan terima kasih dosen-dosen pembimbing yang telah memberikan bimbingan dan arahan dalam penelitian ini. Tidak lupa kepada seluruh sivitas akademika Pendidikan Pancasila dan Kewarganegaraan Universitas Sriwijaya sebagai lembaga akademik tempat penulis menuntut ilmu dalam jenjang sarjana.

\section{Referensi}

Adil Muhammad. (2014). Dinamika pembauran hukum Islam di Palembang mengurai Isi Undang-Undang Simbur Cahaya. Nurani, 14(2), 57-76.

Alfan, M. (2013). Pengantar filsafat nilai.
Bandung: Pustaka Setia.

Amri, P., \& Maharani, S. D. (2018). Tradisi ziarah kubro masyarakat Kota Palembang dalam perspektif hierarki nilai Max Scheler. Jurnal Filsafat, 28(2), 160. https://doi.org/10.22146/jf.36054

Farida, \& Hasan, Y. (2011). Undang-undang Simbur Cahaya sebagai sumber hukum di Kesultanan Palembang. In Seminar Antara Bangsa Perantauan SumateraSemenanjung Malaysia, Sabah dan Serawak. Pulau Pinang-Malaysia.

Gadjahnata, K. O. H., \& Swasono, S.-E. (1986). Masuk dan berkembangnya Islam di Sumatera Selatan. Jakarta: Penerbit Universitas Indonesia.

Ismail, M. A. (2004). Marga di bumi Sriwijaya. Palembang: Unanti Press.

Mulyadi, L. (2013). Eksistensi hukum pidana adat di Indonesia: Pengkajian asas, norma, teori, praktik, dan prosedurnya. Jurnal Hukum dan Peradikan, 2(2), 224246.

Ravico, R. (2015). Konflik elit politik di Kesultanan Palembang Darussalam tahun 1803-1821. TAMADDUN: Jurnal Kebudayaan dan Sastra Islam, 15(2), 39-66.

Santun, D. I. M., Murni, \& Supriyanto. (2010). Iliran dan Uluan: dikotomi dan dinamika dalam sejarah kultural Palembang. Yogyakarta: Eja Publisher.

Sugiyono. (2014). Metode penelitian pendidikan. Bandung: Alfabeta.

Syawaludin, M. (2014). Analisis sosiologis terhadap sistem pergantian sultan di Kesultanan Palembang Darussalam. Intizar, 20(1), 139-161.

Utomo, B. B., Hanafiah, D., \& Ambari, H. M. (2005). Perkembangan Kota Palembang dari Wanua Sriwijaya menuju Palembang modern. Palembang: Dinas Pariwisata dan Kebudayaan Pemerintah Daerah Kota Palembang.

Wijaya, S., Widodo, S. T., \& Subiyantoro, S. (2017). Diction and moral values in the law of the simbur cahaya of customary 
cultural law in the society period of Palembang Sultanate ( pragmatic sociolinguistic studies ). In Proceeding of 2 nd International Conference of Arts Language And Culture (hal. 577-583). Surakarta: Universitas Sebelas Maret.

Wirajaya, A. Y. (2018). Transformasi Palembang menuju kota multikultural : Sebuah refleksi terhadap naskah Undang-Undang Simbur Cahaya dan Tuhfah ar-Raghibin. Shahih, 3(1), 3345.

https://doi.org/10.22515/shahih.v3i1.12 91

Yusdani. (2004). The book of Simbur Cahaya. The receptive theory point of view. Millah, III(2), 235-254. 